area will be resumed in 1964 . Dr. Piero Matthey, also of the Institute, is at present engaged in fieldwork among the Sara of the République du Tchad, in collaboration with the Institut National Tchadien pour les Sciences Humaines, with the help of a grant from the WennerGren Foundation.

\title{
Conference on African Law, Venice, October 1963
}

The Fondazione Giorgio Cini and the Société Africaine de Culture organized a conference in Venice from 3 to 5 October 1963 on African traditional law and its development. Among the resolutions passed by the conference was the recommendation that African countries should undertake a systematic survey and restatement of customary law and attempt to standardize their new laws in the appropriate fields. It was urged that the major Foundations should contribute to this task and that Unesco should provide the countries concerned with technical and material aid for this purpose.

\section{International African Seminar on the Roles of Elites in Contemporary Africa}

THE International African Institute is organizing a seminar on the Emergence of New Social Classes and the Roles of Elites in Contemporary Africa, to be held from Tuesday 14 July to Thursday 23 July 1964 at the University of Ibadan by courtesy of the ViceChancellor, Professor K. O. Dike. The chairman will be Dr. Peter Lloyd of the Department of Sociology, University of Ibadan. This will be the second in a new series of international African Seminars arranged with the aid of a grant from the Ford Foundation.

Papers and discussions at the seminar will include consideration of the following themes: the definition of new social categories, their statuses, attitudes, and influence; their relations to traditional associations, to kinsfolk in other categories, and to the community of origin; family patterns; styles of living; new associations; the significance of wealth and education in new political and economic relations; changes in value patterns; the relevance of concepts of social class, elites, \&c., for the analysis of modern African societies.

\section{'Zeitschrift für Ethnologie': special West African number}

Zeitschrift für Ethnologie, vol. 88, no. 2, 1963, is devoted to articles on West African topics which have been compiled by Dr. Jürgen Zwernemann. The contents are as follows:

Der Gottesname Nyambi im Lichte alter west-afrikanischer Reiseberichte

Zur traditionellen Architektur der westafrikanischen Neger: Der Bauvorgang in den westlichen Guinealändern und in Westsudan

Die Masken der Guéré im Rahmen der Kunst des oberen Cavally-Gebietes

Adangme Varianten zum Thema: Himmelsheil, Himmelsmenschen

Historische Überlieferungen und Gesellschaftsordnung in Kpandu (Ost-Ghana)

Zur Frage megalithischer Elemente bei den Kurumba (OberVolta, Westafrika)

Die drei heligen Lanzen der Kouroumba von Louroum (HauteVolta)

Feldtypen und Speichertypen bei den Kasena in Obervolta

Walter Hirschberg

Herta Haselberger

Hans Himmelheber

Hugo Huber

Richard Mohr

Annemarie SchweegerHefel

Wilhelm Staude

Jürgen Zwernemann 
Notizen zur Eisengewinnung der Hausa

Neue Beiträge zur Kenntnis der Buduma

Kurt Krieger

Völkerkundliche Filmarbeit deutscher Ethnologen in Westafrika

Werner Rutz

\section{'The Scolma Directory of Libraries and Special Collections on Africa'}

THE Standing Conference on Library Materials on Africa (see Africa, October 1962, p. 395) has recently published its Directory of Libraries and Special Collections, covering Great Britain and Eire. The Directory is arranged in alphabetical order of place-names and includes university and public libraries, missionary societies, and African studies institutes, as well as private collections containing materials on Africa, both published and unpublished. A very full index completes this most useful work of reference. Copies of the Directory (1 ss. each, plus $x$. $3 d$. postage) may be obtained from Messrs. W. Heffer \& Sons, Ltd., 3 Petty Cury, Cambridge. The compiler, Mr. Robert Collison (Librarian, B.B.C., Broadcasting House, London, W. I) would be glad to receive any suggestions, amendments, or criticisms for the second edition of the Directory.

\section{' Neologisms in Hausa'}

Mr. T. G. BRIERLY, who supplied the examples of ' French-influenced Hausa' published in Africa, July I963, p. 269, has asked us to point out that the words in his list were rendered as they are pronounced and that they are not normally written. Niger, unlike Northern Nigeria, has no Hausa publications, though broadcasts are made in Hausa. The Gaskiya Corporation, which publishes an extensive Hausa literature in Roman script, did not succeed in creating a market for a Hausa newspaper in the French-speaking territories, where Hausa is not taught in schools and the only written language commonly used is French.

\section{Secretary of the Institute: Retirement of Miss Ailsa Currie}

Miss CuRrie retired from the secretaryship of the Institute at the end of January 1964. She first came to the Institute in 1954 and assisted in preparing the Select Annotated Bibliography of Tropical Africa which was published with a grant from the Twentieth Century Fund of New York. She became Secretary on Mrs. Wyatt's retirement at the beginning of 1958 , when the activities of the Institute were expanding considerably, notably in connexion with the programme of International African Seminars and the series of Field Fellowship awards made possible by the grants of the Ford Foundation. She handled the detailed and often complicated arrangements that these involved with great competence, while many members of the Institute and others who have benefited from these projects have been grateful for the help they have received. Her marked administrative ability and sympathy in securing the smooth working of the office while meeting the personal needs of the staff have been greatly appreciated, and it is much regretted that, owing to family commitments, the Institute has lost her valued services.

Mrs. Olga Wolfe, who has been Assistant Secretary since $196 \mathrm{I}$ and will already be well known to many members of the Institute, has been appointed Secretary from February I964. 